\title{
Structural Analysis of Economic Growth in China: International Comparison Context
}

\author{
O. S. Sukharev ${ }^{1}$, E. N. Voronchikhina ${ }^{2}$ \\ ${ }^{1}$ Institute of Economics of the Russian Academy of Sciences, \\ 32, Nakhimovsky pr., Moscow, 117218, Russian Federation \\ ${ }^{2}$ Perm State National Research University, \\ 15, Bukireva ul., Perm, 614990, Russian Federation
}

For citation: Sukharev O.S., Voronchikhina E. N. (2019) Structural Analysis of Economic Growth in China: International Comparison Context. St Petersburg University Journal of Economic Studies, vol. 35, iss. 4, pp. 543-568. https://doi.org/10.21638/spbu05.2019.403

The Chinese economy over the long term has shown relatively high average growth rates, even considering a gradual slowdown over the last several years. In this regard, it is important to identify features of this model and policies of economic growth in comparison with other countries. Purpose of this research is to conduct a structural analysis of the Chinese economic growth in comparison with the United States, Germany, Japan, and Russia, as well as to identify features of its structural dynamics and macroeconomic policy. The subject of investigation is models of economic growth in these countries, and approaches to macroeconomic growth policy in China and Russia that determine the contribution of GDP components and economic sectors to the rate of economic growth. The hypothesis is that the economy growth model is determined by the dominance of the components and sector in GDP. Three basic growth models are defined. The model based on the dominance of gross consumption in the USA and Russia, investment in China, and a mixed growth model in Germany and Japan. The Chinese economy is close to the "Schumpeterian" growth model. The Russian economy approximates the "Fisher" model, especially in terms of macroeconomic policy requirements. Therefore, to ensure the investment growth model, it is necessary, in addition to encouraging investments, to change the characteristics of structural dynamics, including change in macroeconomic policy instruments.

Keywords: empirical analysis of growth, GDP structure by expenditure, sectoral structure of the economy, comparative analysis, model of economic growth.

\section{Introduction}

The research provides the structural analysis of Chinese economic growth as one of the leaders of world economic development, whose influence nowadays comes to the fore [Hu, Zhang, Chao, 2019; Wang, Chanda, 2018]. Accordingly, it is necessary to identify the structural features of the Chinese economy growth in comparison with the structural growth dynamics in developed countries. It's the USA as the main competitor of China, Germany as the leader of economic development in Europe, Japan as the leader in Southeast Asia and Russia.

The goal of research is to analyze the economy structure and macroeconomic policy in China, which determines the investment economic growth model, which has become the condition for the country's global economic leadership. The comparison is made with

(C) Санкт-Петербургский государственный университет, 2019 
the macroeconomic policy in Russia, which is clearly at odds with the approach to the macroeconomic policy in China.

To achieve the goal of research is required the following tasks:

a) carrying-out of the structural analysis of economic growth by sectors and elements of expenditure of gross domestic product (GDP), determination dominant component with the assessment of growth model of countries and the response of macroeconomic policies to the crisis;

b) identifying growth models, comparing the Schumpeterian's [Schumpeter, 1934 (2008)] and Fisher's growth models, macro parameters comparison of China and Russia such as price dynamics, employment, monetization level and interest rate [Zhao, 2018; Glazyev, 2017].

The Schumpeterian's model means that the suppression of inflation is not an absolute requirement for economic growth, since the upward price movement may not hold back the economic growth. For the Fisher's model, the growth condition is the suppression of inflation.

Comparative analysis of the models of economic growth is considered for the period 2000-2017. The choice of the period is explained by the available statistical data on the websites of the International Monetary Fund and World Bank. As the research methodology the structural analysis is in the use. It allows us to decompose the GDP by expenditure components and assess the contribution of each component to the growth rate. The same applies to the allocation of sectors as basic economic structures, the dynamics of which determine the dynamics of economy (GDP rate).

The authors have identified three basic sectors. There are raw materials, manufacturing and transaction sectors by types of activity according to the Russian National Classifier of Types of Economic Activity ${ }^{1}$. The division of types of activity is subordinated to the realization of the research goal and explained so that Russian economy is characterized by staple trap and the rather large transaction sector. Therefore, it is necessary to give such an allocation of sectors in order to uniformly view the contribution to the growth rate of raw materials, manufacturing and transaction sectors in considered countries. In general, the author's approach to the transaction sector is consistent with the approach of D. North and J. Wallis [Wallis, North, 1988]. There are used other approaches in economic analysis. Such dichotomies are especially prevalent: the transaction-transformation sector, the industrial and post-industrial sectors [Galbraith, 1967; Bell, 1973], or agrarian, industrial and service sectors [Toffler, 1984; Erkoyuncu et al., 2019]. However, such approaches are no less normative than the author's. Of course, it is possible to determine the contribution of sectors by the different composition of elements, but these will also be different ratios within the framework of these dichotomies.

Structural analysis of economic growth allows us to determine the contribution of each component of GDP to the growth rate. Each component occupies the share and grows with the changing pace, so that its contribution changes. Different countries have different economic structure and GDP, so the contribution of the GDP component to the pace will be different. The phenomenon of Chinese economy growth in comparison

${ }^{1}$ Sector allocation according to Russian National Classifier of Types of Economic Activity. URL: http://www.gks.ru/wps/wcm/connect/rosstat_main/rosstat/ru/statistics/accounts/. The GVA of the sectors in the total GDP of the country (accessed: 15.02.2019). 
with the growth of other developed countries requires understanding. This approach considers firstly, the structural dynamics of GDP by elements (gross consumption, investment spending, government spending and net exports). Secondly, the dynamics of sectors (manufacturing, raw materials and transaction sectors) and its contribution to the growth rate. Thirdly, we will determine the characteristics of macroeconomic policy (using regression analysis) of China [Zhou, 2018].

Within the framework of the structure, the contribution of the elements is not allocated equally. For example, if some structure element occupies $70 \%$ of GDP, but it provides dynamics, for one $1 \%$, so that the overall growth is $5 \%$. The element with the $30 \%$ share should grow about $14.4 \%$. The reason is that the large element grows slowly and, in fact, slows down the entire system, sets the possibility of its growth. The nature of communication and mutual influence is pure and simple the system structure. Macroeconomic policy instruments have some influence on the developing relationships between the elements [Teixeira, Queirós, 2016; Araujo, 2013]. However, there is the set of measures, usually of an institutional nature, which fundamentally affects the allocation of resources among the system elements, thereby setting the pace of their dynamics and the mode of interaction. These institutions can relate to monetary and budgetary policies, since the performance of the necessary functions, the provision of resources by each element is representable through its monetary (financial) security [Christiansen, Schindlerand, Tressel, 2013]. Hence, structural policy usually affects the composition of the system elements, share of each elements, as well as the rate of its dynamics. Clearly, the problem of the three groups of structural policy instruments can be posed [Li, Min, 2013; Vries et al., 2012]. However, due to the influence on the laws of the links of elements and their development, such a policy can't be considered in isolation from investment. At the same time, it is important to note that the resource allocation along the directions (elements) of use represents the independent task of structural policy. It relates to which allocation rule to establish, and also how to influence the allocation regime and whether to change it in the future. If the economy is tasked with the purposeful change in the relationships between the elements, then it's impossible to neglect the problem of allocating resources and managing their floating between sectors [Sukharev, 2018].

Modern changes in the economy structure occur quite quickly, especially in the factors of production. It can be caused, for example, by demonetization, external shocks, internal institutional changes etc. [Alonso-Carrera, Raurich, 2015; Bridgman, Duernecker, Herrendorf, 2018]. However, they are always accompanied by either resources allocation or dysfunctions of the basic regulatory institutions (usually it is observed simultaneously). If the imbalances in the structure worsen the economic dynamics (cause the negative change), then usually speak of the structural crisis [Pothen, 2017]. The emergence of technology, innovations also provokes such the crisis, which often ends with the fact that the new technology gives way to the former, not always the replacement and increase in efficiency. Overcoming the crisis, no matter what it may be, and whatever it provoked, requires resources. The bet on new technologies for macroeconomic policies to overcome the crisis does not always work and adequate to the existing new structural and institutional conditions [Samaniego, Sun, 2016; Vu, 2017].

The transmission mechanism of modern macroeconomic policy requires taking into account the structural and institutional features of the economic system. It will require broadening the diversity of the management subject and, if possible, reducing the variety 
of the management object is control parameters. In this way, the principle of TinbergenTeil's "goals-tools" is enlarged at the expense of the formulated position, making the policy more flexible, taking into account the variety of circumstances.

Recent studies of advanced Western economists, in particular V. Smith, confirm this position [Smith, 2017]. So, if there is a crisis of balance sheets, when liabilities exceed the market value of assets, so that negative capital is found in the balance sheet, then the monetary and fiscal policy in a standard form are powerless to affect the macroeconomic situation [Smith, 2017]. Thus, the crisis of 2007 was caused not so much by the lack of liquidity, as by the insolvency of the banking system, which took the form of default. However, Smith goes away from answering the question of the reasons for this insolvency. Nevertheless wishing or not, but it notes the influence of institutions, in particular, banking, on the generation of the economic crisis. If macroeconomic policy does not come from the influence of these institutions and its changes, then it is powerless to change anything radically [Li, Lin, 2017]. In any case, it certainly will not save against the recurrence of the crisis in the relatively short time, even if it can be overcome. Of course, immediately there was the way to eliminate toxic assets, but it can't "clear" the assets completely, because the obligations must be satisfied according to the established rules.

Apparently it is worthwhile to assume that the increase the "toxic assets" occurs not only because of the expansion of speculative principles in economic development, but also in the basic decline in its effectiveness, when life in debt spreads so widely that it is not conditioned [Eicher, Schreiber, 2010].

Smith V. is right that the increase in the money supply, the reduction in the refinancing rate doesn't solve the accumulated problems. There are required institutional changes and not just the financial sphere and markets, the banking system, but also other subsystems of the economy, as well as the structural impacts that would lead to change, the conditions for the efficiency of economic activity.

Of course, it should be noted that the institutes that are being introduced often do not work as they were expected. The striking example is the 1944 Bretton Woods accord. As D. Held, A. McGrew, D. Goldblatt and J. Perraton noted, the first article on the Monetary Fund declared the need for high employment and real incomes in the countries that will adopt this currency system [Held et al., 2004]. Moreover, the emerging new order is the system of institutions initially assumed the priority of the national goals of macroeconomic policy over the goals of the global financial system [Chen, Jefferson, Zhang, 2011; Harada, 2015]. The further history of the institutions and world economy development has shown the completely different order.

To formulate and solve system development problems based on the structural analysis method, some positions should be taken into account.

Firstly, the different composition of elements with different proportions in the system development parameter can give different contributions to the dynamics of this parameter, but the magnitude of the dynamics parameter can be unchanged.

Secondly, the different allocation of resources that occurs according to the return on invested funds (the principle of return on investment) or the profitability of activities (expected and actual as a result of resource development) between the structural elements of the economic system can give approximately the same ratio of profitability and risk and the system development rate [Ciarli, Valente, 2016]. This aggravates the problem of financial (investment) resources allocation, when different elements of the system produce the 
same dynamics [Święcki, 2017]. The different structure of resource allocation gives the similar result. It is the specific point, since it will be necessary to determine for it which economic elements structure to choose and how to allocate the resource, if this allocation is different and the gross total is similar.

Thirdly, the choice of the economic structure and the model of the resources allocation within its framework are conjugate tasks, the complexity of solving which with the concurrence of the outcome increases, however, it exists and when different structures of elements and resource allocation between them give different results. Even in this case, we will have to choose some kind of growth model, benchmarks in the transformation of the economic structure.

Structural analysis of the economy is strategically oriented, since it allows us to touch upon the fundamental laws of communication of the system elements that ensure its dynamics. It can be conducted in different directions, but always gives the idea of the current composition and state of the object, which is being conducted.

\section{Research Methodology. Content of Structural Analysis}

The research provides the structural analysis of the existing models of economic growth in some countries by the dynamics of economic sectors and the GDP component by expenditure with the contribution of each component and sector to the economic growth. This will make it possible to identify the dominant component and the sector, as well as to give the aggregate assessment of the growth model.

Let us present the formula for calculating the growth rate by the elements of GDP by expenditure (final consumption expenditure of households, $C$; final consumption expenditure of public administration, $G$; gross capital formation, I; net exports, $N X$ ) [Sukharev, 2016a]:

$$
g=g C \cdot c+g I \cdot i+g G \cdot g+g N X \cdot n x
$$

where:

the share of elements in GDP: $c=(C / Y) \cdot 100 ; g=(G / Y) \cdot 100 ; i=(I / Y) \cdot 100 ; n x=$ $=(N X / Y) \cdot 100$; growth rate of components of GDP: $g C$ is the growth rate of final consumption expenditure of households, \%; $g G$ is the growth rate of final consumption expenditure of public administration, \%; $g I$ is the growth rate of gross capital formation, $\%$; $g N X$ is the growth rate of net exports, \%.

The calculation according to the formula (1) requires the statistical information. The input data for the components of GDP by expenditure are formed in the prices of the base year 2000.

Similarly, to formula (1) the sectoral structure of GDP is estimated with the contribution of each sector to economic growth:

$$
g=g A \cdot a+g B \cdot b+g C \cdot c,
$$

where:

share of sectors in GDP: $a=(A / Y)^{\star} 100 ; b=(B / Y)^{\star} 100 ; c=(C / Y)^{\star} 100$; gross value added (GVA) growth rate of sectors: $g A$ is the growth rate of the raw material sector GVA, $\% ; g B$ is the growth rate of the manufacturing sector, $\% ; g C$ is the growth rate of the transaction sector, \%. 
To calculate the formula (2) will need grouping by three sectors of the economy (raw materials, manufacturing and transaction sector) according to Russian Standard Industrial Classification of Economic Activities (RSICEA) addition of GVA activities. Let us present the articles of the RSICEA in the form of the following groups by sectors:

(A) raw materials sector (agriculture, hunting and forestry, $A$; fisheries, fisheries, $B$; mining, $C$; production and allocation of electricity, gas and water, $E$ );

(B) manufacturing sector (manufacturing, $D$; construction, $F$ );

(C) transaction sector (wholesale and retail trade; repair of motor vehicles, motorcycles, household goods and personal utensils, $G$; hotels and restaurants, $H$; transport and communications, $I$; financial activities, J; operations with real estate, rent and granting of services, $K$; public administration and military security; social insurance, $L$; education, $M$; health and social services, $N$; other community, social and personal service activities, $O$ ).

In the calculation of formulas (1) - (2) are estimated accuracy by comparing the calculated values and actual growth rates of GVA by sectors and elements of expenditure.

Then we will conduct the empirical analysis of the economic growth structure by GDP components and sectors for the countries: Russia, USA, Germany, Japan and China. Such the analysis is necessary to identify the specific structural features of the Chinese growth model in comparison with other countries.

\section{Structural Analysis of GDP Components and Their Contribution to the Economic Growth Rate}

The authors conduct comparative empirical analysis of the existing models of economic growth in different countries on the dynamics of the GDP components by expenditure with the establishment of the contribution of each component of GDP in the growth rate. This will highlight dominant component and give the aggregated estimate of the growth model. Within this framework, the new growth stimulation policy may be needed to change the contribution to the rate of GDP growth of its components, as the model of industrial growth on the new technological basis may require such this change as the framework condition for further development.

We present the results of empirical analysis of the structure of economic growth by components of GDP in some countries [Sukharev, 2017].

It is commonly known that the gross product can be written down as

$$
Y=C+I+G+N X,
$$

where $C$ is consumer spending, $I$ is investment spending, $G$ is government spending, $N X$ is net exports; $c, n, a, b$ are shares of each of the components of the gross product respectively. We shall handle analytically the rate of change of the product $(g=(1 / Y) d Y / d t)$ through the rate and share of each GDP components. Then the growth rate of the product will be [Sukharev, 2016a]:

$$
g=g c c+g I n+g G a+g N X \quad b .
$$

Figures 1-5 (see Appendix) show the structural dynamics of the gross product of five countries, which demonstrate the contribution to the rate of economic growth of GDP each components for the country. As we see, the growth rate value varies by country, but 
the dynamics and contribution to this dynamics of the GDP component by expenditure also change. It is this difference is the important characteristic of the model of economic growth. It is relevant and critical for the organization of a forward-looking growth model, especially if the task of industrialization is set, for example, for the Russian economy.

Figure 6 reflects the deviation of the calculated from actual rate of GDP growth for the countries, with the deviation in the most crisis year not exceeding $5 \%$, in other years significantly less, no more than $2-3 \%$, which indicates the acceptable accuracy of the calculations performed.

Analysis of the data obtained from the Russian economy entitle to arguable that the main contribution to the growth rate was made by consumer spending, followed by investment spending (fig. 1, see Appendix), followed by government spending. During the crisis of 2009 and 2014-2015 contribution to the growth rate net exports exceeds not only government spending, but also the contribution of all other components of GDP that make a negative contribution. Thus, only through net exports the economy resisted the crisis in these years. It should be particularly noted that in 2009 the largest decline was in investment spending and in 2015 is consumer spending, although investment also made negative contribution to the growth rate. It was investment spending made the biggest contribution to the growth rate only in 2010-2011 in Russia relative to the other GDP components. If before 2009 the main contribution to the growth rate was given by gross consumption, then after 2010 the situation changes. Investment costs are leading for two years, then again gross consumption is until 2014, with the investment crisis starting in 2013 (the contribution of investments in GDP dynamics is negative, fig. 1, see Appendix). Already in 2014 gross consumption on the contribution to the GDP rate is on the second place, at the first is net exports. Not without interest is the 2016 year, when all components, with the exception of government spending, give a little less than zero contribution to the economic dynamics and in 2017 the positive contribution is given by gross consumption and investment with latter reaching the first position (fig. 1, see Appendix). Is it possible to consider 2017 as the year of transformation of the growth model when investments will make the main contribution to GDP dynamics, rather than consumption. Such the task can and should be put in the framework of the macroeconomic policy. However, the crisis of consumption and investment are two negative processes that have been revealed in the Russian economy, starting from 2014 (consumption) and 2013 (investment), respectively, until 2017. It's difficult to restore positions quickly as resources are allocated between the growth of investment and consumption [Sukharev, 2016b].

Analyzing the structural dynamics of GDP in the US, Germany, Japan and China (fig. 2-5, see Appendix), it can be said that the general is net exports don't give the fundamental contribution to the GDP dynamics of these countries. Moreover, in the 2007-2009 crisis years it absolutely doesn't affect the GDP dynamics.

The structural analysis of the Chinese economic growth in comparison with other developed countries show that in 2000-2014 the main generator of economic dynamics was investment cost (fig. 5, see Appendix) in contrast to the Russian economy and the United States, where the main contribution to the growth rate was gross consumption, but not investment. In 2017-2018 when the growth rate of the Chinese economy slowed, gross consumption began to compete with investment cost on contribution to the growth rate and come to the foreground in 2017. Table 1 sums up the impact of GDP components in China, Russia and the US in responding to the crisis. 
Table 1. Influence of GDP elements of China, Russia, USA, Germany and Japan on economic dynamics during the crisis

\begin{tabular}{|c|c|c|}
\hline Country/Reaction & $\begin{array}{c}\text { Component of GDP, } \\
\text { counteracting the recession }\end{array}$ & $\begin{array}{c}\text { Component of GDP, } \\
\text { providing the recession }\end{array}$ \\
\hline $\begin{array}{c}\text { Russia } \\
\text { figure 1) }\end{array}$ & Net export & $\begin{array}{c}\text { Gross consumption, } \\
\text { investment spending, } \\
\text { government spending, }\end{array}$ \\
\hline $\begin{array}{c}\text { United States } \\
\text { (figure 2) }\end{array}$ & Government spending & $\begin{array}{c}\text { Gross consumption, } \\
\text { investment spending, } \\
\text { net export }\end{array}$ \\
\hline $\begin{array}{c}\text { Germany } \\
\text { (figure 3) }\end{array}$ & $\begin{array}{c}\text { Gross consumption, } \\
\text { government spending }\end{array}$ & $\begin{array}{c}\text { Investment spending } \\
\text { Japan } \\
\text { (figure 4) }\end{array}$ \\
\hline $\begin{array}{c}\text { Gross consumption, } \\
\text { government spending }\end{array}$ & $\begin{array}{c}\text { Investment spending, } \\
\text { gross consumption, } \\
\text { government spending }\end{array}$ & Net export \\
\hline
\end{tabular}

Table 1 summarizes the response of elements of GDP to the crisis in the countries (2009 and 2015). The elements of GDP that counteracting and providing the recession are highlighted. In Russia during the crisis 2009 and 2015 years net exports became the stimulating factor, while gross consumption and investment spending showed the negative contribution to the growth. For the German economy, gross consumption in recent years (which excludes 2002) made the significant positive contribution to the economic growth rate. Investment spending, on the contrary, keep growth down of the German economy, especially in 2002, 2009, 2012. In Germany during the crisis years of 2008-2009 government spending became the main growth factor. For Japan, in addition to government spending, gross consumption became the positive factor. However, investment spending became the constraining condition for the Japanese economy growth.

The main contribution to economic dynamics for the United States is made by gross consumption, which competes in certain years with investment spending, coming out on the first place on the contribution to the economic growth rate. However, in the 2009 crisis investment spending gives the most negative contribution to the growth rate and the economy is opposed by the crisis through government spending.

The structural dynamics of GDP in Germany and Japan is changeable. There are dominated gross consumption, then government, investment spending, without an explicit long-term contribution to the growth rate of someone component. At the same time fluctuations in the contribution of investment spending to growth dynamics are the most significant for Germany and Japan. The contribution of investment spending is one of the lowest among the countries. Germany and Japan respond to the crisis are very similar by increasing in the contribution to the growth rate of government spending and for Japan also slightly is consumption (fig. 3, 4, see Appendix).

Specially focus on the structural dynamics of China's GDP as this country demonstrates the different growth model from other countries. Firstly, the layerwise arrangement 
of the contribution of GDP components is clearly distinguished (fig. 5, see Appendix) with the dominance in this contribution over the significant time interval of investment spending. Gross consumption takes second and government spending is the third positions on the contribution to the growth rate. This model can be considered investment model of economic growth. Secondly, while maintaining the leading contribution of investments to the growth rate of China's GDP, conspicuous is the fluctuation of this contribution by almost $200 \%$ greater. None of the considered economic systems shows such fluctuations in the contribution of GDP components to its dynamics. It should also be noted that in the 2009 crisis in other countries the contribution of investment and consumption became negative and in China it was positive and increased. Consequently, this country demonstrates different model of growth/development, fundamentally different in terms of quality characteristics and the main parameters of the dynamics. The remarkable thing is that China shows the model of industrial growth, that is, it increases the manufacturability of basic production and the economy.

Thus, Russia and the United States as the main generator of growth had consumer spending at the considered time interval, China is investment spending, while Germany and Japan had the mixed model without strong tendency.

Further, we will consider the influence of the economy sectoral structure of the countries on the rate of economic growth, determining the contribution of each of three sectors (raw materials, manufacturing and transaction sectors).

\section{Structural-sectoral Analysis of Economic Dynamics}

The economies of Russia, the US, Germany, Japan and China are characterized by the dominance of the transaction sector in the structure of GDP. However, the contribution of the sector to the rate of economic growth is different (fig. 7-11, see Appendix).

Let's consider sectoral dynamics that form the rate of the country's economic growth. For Russia, there are three sectors (raw material sector, manufacturing and transaction sector) by GVA in 2004-2018:

1) raw material sector (agriculture, hunting, forestry and fishing; mining; production and allocation of electricity, gas and water; $A, B, C, E$ types of economic activity);

2) manufacturing sector (manufacturing; construction; $D, F$ types of economic activity);

3) transaction sector (wholesale and retail trade; repair of motor vehicles, motorcycles, household products and personal items; restaurants and hotels; transport and communications; financial activities; real estate operations, renting and provision of services; state administration and ensuring military security; social insurance; education; health regulations and social services; provision of other communal, social and personal services; $G-O$ types of economic activity).

The same three sectors are considered for GVA in 1998-2015 for the US, Germany, Japan and China. The selected sectors correspond to the International Standard Industrial Classification of All Economic Activities (ISIC).

The share of the transaction sector in Russia's GDP changed from 58 to $64 \%$ over the period 2004-2017. This sector in the US is much larger reaching $80 \%$ of GDP. Its dynamics makes the greatest contribution to the rate of economic growth. However, in Russia this contribution reached in the largest measure $6 \%$, in the USA is $3.2 \%$ (fig. 7-8, 
see Appendix). It should be noted that in Russia the raw material sector didn't decisive contributed to the economic growth rate. It occupied the third position in terms of its contribution to growth mostly. In certain years it was the raw material sector ensured economic dynamics, in particular during the years of the crisis of 2009, 2015-2016, and in addition in 2013-2014 and in the period until 2004. The share of the raw material sector of Russia was below $20 \%$ of GDP, manufacturing sector is about $25 \%$. The US manufacturing sector accounted for less than $15 \%$, the raw material sector is less than $10 \%$ of GDP. For this reason, the American economy is often presented as the new kind of so-called "service economy". But for the US economy the raw material sector is in the second place in terms of contribution to the growth rate taking back seat the manufacturing sector. At the time of the 2009 crisis transaction sector is the most shrinking in the USA, manufacturing sector in Russia, although the transaction sector also contributes negatively to the GDP dynamics.

The share of the manufacturing sector in countries is higher than the share of raw material sector in GDP, while the transaction sector has the upper hand. At the same time, the contribution of the sectors to the economic growth rate is changing. The transaction sector in Germany and Japan is about $70 \%$ of GDP, manufacturing sector is slightly higher than $20 \%$, raw material sector is little below $10 \%$. Thus, in these countries transaction sector is $10 \%$ higher than in Russia and $10 \%$ lower than in the USA. However, the contribution of this sector to the economic growth rate is considerably less than in Russia and the USA (fig. 9-10, see Appendix).

Manufacturing sector in Japan contributes almost the same contribution to the economy growth rate as the transaction sector, in some years the raw material sector is the second-largest contributor. For Germany the situation is similar, even the contribution to the graphs (fig. 9, see Appendix) is reminiscent of the contribution of sectors in Japan (fig. 10, see Appendix). Sectors exhibit commensurate dynamics in its contribution to the growth rate. This point to the fact that the smallest sectors show more growth (it's related to the manufacturing sector). Transaction sector, where the services are concentrated, shows significantly less growth. Transaction sector of China demonstrated growth in the period 1997-2017 from 35 to $50 \%$ of GDP. At the same time, the share of manufacturing sector remained a little over $30 \%$, while the raw material sector decreased from 30 to $20 \%$ by increasing the share of the transaction sector. Even if the proportionality in the growth rate of the three sectors remains at the same level, its contribution to the growth rate of China's GDP has become decisive, the contribution of the manufacturing sector is the next in importance (fig. 11, see Appendix).

Hence, the transaction sector had the decisive influence on the rate of economic growth and presumably on the level of industrialization and development of manufacturing sector (fig. 7-11, see Appendix). Manufacturing sector in these countries dominates the contribution to economic growth, but after transaction sector (table 2). This significantly changes the concept of industrialization, emphasizing in it not so much the share of manufacturing sector in GDP as the technological level of manufacturing sector. Therefore, it is necessary not so much to increase manufacturing sector in the structure of GDP as change the technological level of manufacturing sector [Lee, McKibbin, 2018].

Let us compare the sectoral dynamics of the countries, determining the average contribution of sectors over the entire period of time and the average growth rate. The results are summarized in table 2. 
Table 2. The average rate of economic growth and the contribution of sectors to the rate of economic growth on average over the period

\begin{tabular}{|l|c|c|c|c|}
\hline \multicolumn{1}{|c|}{ Country/Sector } & $\begin{array}{c}\text { Raw } \\
\text { materials }\end{array}$ & Manufacturing & Transaction & $\begin{array}{c}\text { Average rate } \\
\text { of economic } \\
\text { growth }\end{array}$ \\
\hline Russia (2004-2018) & 0.6 & 0.5 & 1.9 & 3.0 \\
\hline USA (2000-2016) & 0.1 & 0.2 & 1.5 & 1.8 \\
\hline $\begin{array}{l}\text { Germany } \\
\text { (2000-2017) }\end{array}$ & 0.1 & 0.5 & 1.0 & 1.7 \\
\hline Japan (2000-2016) & 0.1 & 0.4 & 0.6 & 1.0 \\
\hline China (2000-2017) & 2.5 & 2.8 & 4.2 & 9.5 \\
\hline
\end{tabular}

B a se d o n: Federal State Statistic Service. URL: http://www.gks.ru/wps/wcm/connect/rosstat_main/ rosstat/ru/statistics/accounts/ (accessed: 28.02.2019); Russian National Bureau of Statistics of China. URL: https://www.stat.go.jp/english/data/index.html (accsessed: 28.02.2019); Central Intelligence Agency. URL: https://www.cia.gov/library/publications/the-world-factbook/ (accessed: 28.02.2019); Federal Statistical Office (Destatis). URL: https://www.destatis.de/EN/Home/_node.html (accessed: 28.02.2019); Statistics Japan. URL: https://www.stat.go.jp/english/data/index.html (accessed: 28.02.2019).

From table 2 it follows that China is the absolute leader from viewpoint of average annual growth rates $(9.5 \%)$ both among the countries under consideration and among countries of the world. Russia ranks second in terms of the average annual growth rate among the countries reviewed here, which also shows the high level of growth $3.0 \%$ on average for the years 2004-2018. The growth of the Russian economy occurred mainly due to the significant contribution of the transaction sector $1.9 \%$ on average over the period. The contribution of the transaction sector of Russia exceeds the contribution of this sector to the GDP of the USA (1.5\%), Germany (1.0\%) and Japan (0.6\%). The similar conclusion can be made with respect to the raw material sector, whose growth in Russia was on average $0.6 \%$. The contribution of the manufacturing sector to Russia's GDP was $0.5 \%$ on average over the period, the same contribution from Germany $(0.5 \%)$, followed by Japan $(0.4 \%)$ and the USA $(0.2 \%)$. The contribution of each of the sectors of the Chinese economy significantly exceeds the contribution of the sectors of the rest of the analyzed countries.

Next, we will focus on the main approaches to macroeconomic policy in China and Russia, specifying which growth model the Schumpeterian's or Fisher's growth model is approaching in these countries. The analysis does not include all countries for which structural analysis was carried out. There are considered two leaders in terms of growth and contribution to the rate of the transaction sector, although the share of the transaction sector, for example, in the US is higher than in Russia and China, and the contribution is clearly less ${ }^{2}$. Hence, in China and Russia the significant contribution of the transaction sector is highlighted and the economic growth rate on average over the period is the largest, but the macroeconomic policies are different. Also the structural models are different. There are the investment growth model in China and consumer growth model in Russia.

${ }^{2}$ Federal State Statistic Service. URL: http://www.gks.ru/wps/wcm/connect/rosstat_main/rosstat/ru/ statistics/accounts/; Central Intelligence Agency (accessed: 20.02.2019); URL: https://www.cia.gov/library/ publications/the-world-factbook/; National Bureau of Statistics of China (accessed: 20.02.2019); URL: https://www.stat.go.jp/english/data/index.html (accessed: 20.02.2019). 


\section{Instruments of Macroeconomic Policy in Growth Models}

The main objective of the comparative analysis of the macroeconomic growth policies of China and Russia is the determination of the general and differences between the Schumpeterian's and Fisher's growth models.

Based on table 2, which shows the sector's average contribution to the economic growth rate, we note, that for a country it is important to have a macroeconomic policy that affects the economic model and the dynamics of the components of GDP and sectors. Considering this, we will conduct the comparative macroeconomic analysis of policy in China and Russia, since it contrasts significantly due to differences in the growth model. For the comparative analysis of the group of countries, we focus on macroeconomic policies in China and Russia.

The Chinese economy in terms of the relationship between the dynamics of macroeconomic parameters shows Schumpeter's growth (as opposed to Fisher's growth that it is necessary to suppress inflation for economic growth).

China's employment, monetization and GDP had been growing in the 2000-2017. However, inflation has increased to $8 \%$, has decreased to zero. Real interest rate varied from $2-5 \%$ for the period. The growth of the money supply contributes to the GDP growth (fig. 12, see Appendix).

There is no exact link between the impact of inflation on GDP change (fig. 13, see Appendix).

Tables 3-4 lists the matrix of pair correlations for the macroeconomic parameters of China and Russia.

Table 3. Matrix of pair correlations of macroeconomic parameters in China in 2000-2017

\begin{tabular}{|l|c|c|c|c|c|}
\hline & GDP & Inflation & Employment & M2 & $\begin{array}{c}\text { Real } \\
\text { interest rate }\end{array}$ \\
\hline GDP & 1 & -0.286 & 0.964 & 0.994 & 0.247 \\
\hline Inflation & -0.286 & 1 & -0.326 & -0.343 & -0.975 \\
\hline Employment & 0.965 & -0.326 & 1 & 0.977 & 0.268 \\
\hline M2 & 0.995 & -0.343 & 0.977 & 1 & 0.293 \\
\hline Real interest rate & 0.247 & -0.975 & 0.268 & 0.293 & 1 \\
\hline
\end{tabular}

B ased on: IMF World Economic Outlook Database. URL: https://www.imf.org/external/pubs/ft/ weo/2019/01/weodata/index.aspx (accessed: 20.02.2019).

The link between employment and inflation is such for the Chinese economy that Phillips correlation is not obvious (below inflation is more employment, although the link in table 3 is not strong). For the Chinese economy, as can be seen from table 2, the most significant impact on economic dynamics exerted the money supply, employment and real interest rate. The decline of that is accompanied by upturn in inflation, increase is the decline in inflation.

The analysis of macroeconomic dynamics in China shows that there is the close relationship between M2, GDP and employment. The monetization of China's economy sup- 
ports economic growth without excessive inflationary pressure. Of course, this conclusion does not answer the question of how much monetization this "rule" will be maintained, but monetization played positive role in supporting the dynamics of China's economy in the period 2000-2017. There is the inverse relationship between the real interest rate and inflation that is with the growth of the rate to $4 \%$ inflation decreases and inversely. Increase of nominal interest rate is accompanied by increase in prices.

Table 4. Matrix of pair correlations of macroeconomic parameters in Russia in 2000-2017

\begin{tabular}{|l|c|c|c|c|c|}
\hline & GDP & Inflation & Employment & M2 & $\begin{array}{c}\text { Real interest } \\
\text { rate }\end{array}$ \\
\hline GDP & 1 & -0.342 & -0.797 & 0.967 & -0.846 \\
\hline Inflation & -0.342 & 1 & 0.534 & -0.887 & 0.450 \\
\hline Employment & -0.797 & 0.534 & 1 & -0.887 & 0.611 \\
\hline M2 & 0.967 & -0.492 & -0.887 & 1 & -0.856 \\
\hline Real interest rate & -0.846 & 0.450 & 0.611 & -0.856 & 1 \\
\hline
\end{tabular}

B a sed on: IMF World Economic Outlook Database. URL: https://www.imf.org/external/pubs/ft/ weo/2019/01/weodata/index.aspx (accessed: 20.02.2019).

Table 4 shows that the strongest direct link between GDP and M2. There is the average positive relationship between the level of inflation and employment, which confirms the presence of the Phillips curve for Russia. The negative relationship is observed between GDP and employment, GDP and interest rate, inflation and M2. GDP growth is accompanied by the slight increase in inflation, which confirms to the greater degree the manifestation of the 'Fisher' model of economic growth.

This is the specificity of the Russian macroeconomic dynamics that significantly different from the dynamics of the Chinese economy macro parameters. This is also the difference in macroeconomic policy approaches.

We will analyze the dynamics of the main macroeconomic parameters of the Chinese and Russian economies.

Figure $14(a, b)$ shows the dependence of China's GDP (a) and Russia (b) on inflation. For the Russian economy there is inverse relationship. The Chinese economy is characterized by the weak link between GDP and inflation, which indicates its proximity to the 'Schumpeterian' growth model. But China's macroeconomic policy is not aimed at suppressing inflation to spur growth. The acceleration of economic growth in China could be accompanied by the increase in the inflation.

Figure $15(a, b)$ shows the effect of inflation on employment in China and Russia. The dependence for countries is multidirectional. The Russian economy is characterized by the direct relationship between macro indicators such as inflation and employment, i.e. the effect is close to the Phillips curve. For the Chinese economy, it almost does not work, and employment growth is accompanied by a decrease in inflation.

The analysis of the main macroeconomic indicators of Chinese and Russian economy allows us to summarize the main conclusions for macroeconomic policy in table 5. 
Table 5. Comparison of the macroeconomic dynamics of China and Russia, 2000-2017

\begin{tabular}{|l|l|l|}
\hline \multicolumn{1}{|c|}{ Macro parameters } & \multicolumn{1}{|c|}{ China $^{*}$} & \multicolumn{1}{c|}{ Russia $^{* *}$} \\
\hline $\begin{array}{l}\text { Type of transfer mechanism } \\
\text { of macroeconomic policy }\end{array}$ & $\begin{array}{l}\text { Growth according to the } \\
\text { Schumpeterian's model }\end{array}$ & $\begin{array}{l}\text { Growth according to the Fisher's } \\
\text { model }\end{array}$ \\
\hline M2, GDP and employment & $\begin{array}{l}\text { M2 growth - GDP and } \\
\text { employment growth }\end{array}$ & $\begin{array}{l}\text { M2 growth - GDP growth, } \\
\text { employment decline }\end{array}$ \\
\hline Interest rate and GDP & $\begin{array}{l}\text { Interest rate growth - GDP } \\
\text { growth }\end{array}$ & Interest rate decline - GDP growth \\
\hline Inflation and GFP & $\begin{array}{l}\text { There is no explicit correlation. } \\
\text { Inflation growth - GDP } \\
\text { growth*** }\end{array}$ & Lower inflation - weak GDP growth \\
\hline $\begin{array}{l}\text { Inflation and employment. } \\
\text { The existence of Phillips } \\
\text { curve }\end{array}$ & There is no explicit correlation. & $\begin{array}{l}\text { Inflation growth - employment } \\
\text { growth, decrease in inflation - decline } \\
\text { in employment }\end{array}$ \\
\hline
\end{tabular}

Note s: ${ }^{*}$ - figures 12-15 (see Appendix), table 3; ${ }^{* *}$ - figures 12-15 (see Appendix), table 4; ${ }^{* *}$ although for the Chinese economy, with low inflation, there is both low and high GDP growth in the 20002017 interval.

Based on: IMF World Economic Outlook Database. URL: https://www.imf.org/external/pubs/ft/ weo/2019/01/weodata/index.aspx (accessed: 20.02.2019).

The increase of money supply does not upturn inflation in the Chinese economy, as the increase in the interest rate accompanied by the inflation reduction. Phillips correlation has no effect for the Chinese economy. There is the increase in employment with the decrease in inflation in 2000-2017 and only in 2017 there was the slight drop in employment. The obvious success of China and improving the competitiveness of economy in the global system causes "competitive objections", taking the form of dirty competitive development restraint, including in the form of sanctions.

Therefore, summing up the analysis of macroeconomic policies in China and Russia, we note that the measures of the policy were consistent with and supported the model of economic growth - investment and consumer respectively.

\section{Conclusion}

Conducting comparative analysis of the economic growth structure in Russia, the United States, Germany, Japan and China, applying the apparatus of structural analysis, in particular, the formula previously proposed by the first author [Sukharev, 2016b], we have drawn the following main conclusions.

Firstly, the structural analysis of growth models in different countries actually changes the accents of the macroeconomic growth policy and also specifies the settings of the economic development strategy in different countries. It allows understanding the contribution of the GDP components and sectors of the economy to the dynamics. Of course, in the future, it's necessary to take into account the influence of various factors on the dynamics of GDP components and sectors, as well as economic policy measures undertaken within the sectoral, fiscal, monetary and other policies. 
Secondly, at least three basic growth models have been identified. One of them based on the dominance of gross consumption (the USA and Russia), other based of investments in China and the mixed growth model in Germany and Japan. The main contribution to the growth rate made by the transaction sector, however, the manufacturing and raw material sectors made different contribution to economic growth rate. For example, in Japan and Germany this contribution is almost the same over the significant period of time. In other countries it is different. Thus, the economy sectoral structure of each country determines the dynamic of economic models and further development. The size of transaction sector differs in countries. It is the largest in the US, which sets the specific technological structure for economy development, expanding the possibilities of introducing digital technologies that have powerful infrastructural effects and are most acceptable in the "service economy".

Thirdly, the conducted analysis of the Chinese economic growth has shown that in 2000-2017 the main generator of economic dynamics was investment spending. Analysis of influence of GDP elements of China on economic dynamics during the crisis confirmed that, in Chinese economy investment spending, gross consumption and government spending counteracted the recession. The relationship between employment and inflation for the Chinese economy has evidentiated, that Phillips correlation is not obvious (below inflation is more employment). The growth of the Chinese economy is close to the Schumpeterian's growth model. Therefore, for macroeconomic growth policies suppression inflation is not necessary. Interest rate growth leads to inflation reduction. Thus, Phillips curve has no effect. The Russian economy shows growth close to the Fisher' model, when inflation is suppressed as the condition of growth, and Phillips correlation is valid.

The above results showed that the Russian economy on the main dominant contribution to the economic growth rate was the gross consumption and transaction sector, and this contribution is second place to the Chinese economy.

\section{References}

Alonso-Carrera J., Raurich X. (2015) Demand-based structural change and balanced economic growth. Journal of Macroeconomics, vol. 46, pp. 359-374.

Araujo R. A. (2013) Cumulative causation in a structural economic dynamic approach to economic growth and uneven development. Structural Change and Economic Dynamics, vol. 24, pp. 130-140.

Bell D. (1973) The coming of post-industrial society: A venture of social forecasting. N.Y., Basic Books. $507 \mathrm{p}$.

Bridgman B., Duernecker G., Herrendorf B. (2018) Structural transformation, marketization, and household production around the world. Journal of Development Economics, vol. 133, pp. 102-126.

Chen S., Jefferson G. H., Zhang J. (2011) Structural change, productivity growth and industrial transformation in China. China Economic Review, vol. 22, pp. 133-150.

Christiansen L., Schindlerand M., Tressel T. (2013) Growth and structural reforms: A new assessment. Journal of International Economics, vol. 89, pp. 347-356.

Ciarli T., Valente M. (2016) The complex interactions between economic growth and market concentration in a model of structural change. Structural Change and Economic Dynamics, vol. 38, pp. 38-54.

Eicher T. S., Schreiber T. (2010) Structural policies and growth: Time series evidence from a natural experiment. Journal of Development Economics, vol. 91, pp. 169-179.

Erkoyuncu J.A., Rajkumar R., Shehab E. et al. (2019) An effective uncertainty based framework for sustainable industrial product-service system transformation. Journal of Cleaner Production, vol. 208, pp. $160-177$.

Galbraith J. K. (1967) The New Industrial State. Boston, Houghton Mifflin. 427 p. 
Glazyev S. Yu. (2017) The battle for leadership in the twenty-first century. Russia, USA, China. The seven options in the near future. Moscow, Knizhnyj mir. 352 p. (In Russian).

Harada T. (2015) Structural change and economic growth with relation-specific investment. Structural Change and Economic Dynamics, vol. 32, pp. 1-10.

Held D., McGrew A., Goldblatt D., Perraton J. (2004) Global Transformations: Politics, Economy, Culture. Cambridge, Polity Press. 540 p.

Hu M., Zhang J., Chao C. (2019) Regional financial efficiency and its non-linear effects on economic growth in China. International Review of Economics \& Finance, vol. 59, pp. 193-206.

Lee J. W., McKibbin W. J. (2018) Service sector productivity and economic growth in Asia. Economic Modelling, vol. 74, pp. 247-263.

Li K., Lin B. (2017) Economic growth model, structural transformation, and green productivity in China. Applied Energy, vol. 187, pp. 489-500.

Li W., Min G. (2013) China's Growth Model and Structural Imbalance in the Open Economy. Procedia Social and Behavioral Sciences, vol. 77, pp. 37-54.

Pothen F. A. (2017) Structural decomposition of global Raw Material Consumption. Ecological Economics, vol. 141, pp. 154-165.

Samaniego R.M., Sun J.Y. (2016) Productivity growth and structural transformation. Review of Economic Dynamics, vol. 21, pp. 266-285.

Schumpeter J. A. (2008) The Theory of Economic Development: An Inquiry into Profits, Capital, Credit, Interest and the Business Cycle. Translated from the German by Redvers Opie. New Brunswick (U.S.A) and London (U.K.), Transaction Publishers. 864 p.

Smith V. (2017) Rethinking the Economy: Classical Understanding. Collection Economics for the Curious. What do Nobel laureates think about? Moscow, Gaidar Publishing House.

Sukharev O.S. (2016a) Economic growth in Russia: the problem of management, Economist, vol. 7, pp. 2131. (In Rissian).

Sukharev O. S. (2016b) Theory of Economic Restructurization. Moscow, Lenand. 256 p. (In Russian)

Sukharev O. S. (2017) Empirical facts to the theory of reform and economic growth. Economics and Entrepreneurship, vol. 2, pp. 26-37. (In Russian)

Sukharev O.S. (2018) Changes in macroeconomic policies to ensure economic growth in 2018-2024. Problems of Management Theory and Practice, vol. 3, pp. 113-119. (In Russian)

Święcki T. (2017) Determinants of structural change. Review of Economic Dynamics, vol. 24, pp. 95-131.

Teixeira A.A., Queirós A.S. (2016) Economic growth, human capital and structural change: A dynamic panel data analysis. Research Policy, vol. 45, pp. 1636-1648.

Toffler A. (1984) The Third Wave: The Classic Study of Tomorrow. USA, Bantam. 560 p.

Vries G. J., Erumban A. A., Timmer M.P., Voskoboynikov I., Wu H.X. (2012) Deconstructing the BRICs: Structural transformation and aggregate productivity growth. Journal of Comparative Economics, vol. 40, pp. 211-227.

Vu K. M. (2017) Structural change and economic growth: Empirical evidence and policy insights from Asian economies. Structural Change and Economic Dynamics, vol. 41, pp. 64-77.

Wang T., Chanda A. (2018) Manufacturing growth and local employment multipliers in China. Journal of Comparative Economics, vol. 46, pp. 515-543.

Zhao J., Tang J. (2018) Industrial structure change and economic growth: A China-Russia comparison. China Economic Review, vol. 47, pp. 219-233.

Wallis J. J., North D. C. (1988) Measuring the transaction sector in the American Economy. Chicago and London, University of Chicago Press. $161 \mathrm{p}$.

Zhou C. (2018) State Capture and Technological Innovation During Institutional Transition: Empirical Evidence from Listed Companies in China’s Growth Enterprise Market. Transformations in Business \& Economics, vol. 17, pp. 180-193.

Received: 22.03.2019

Accepted: 11.09.2019

Authors' information:

Oleg S. Sukharev — Dr. Sci in Economics, Professor; o_sukharev@list.ru

Ekaterina N. Voronchikhina — PhD in Economics, Senior lecturer; envoronchikhina@gmail.com 


\section{Appendix}

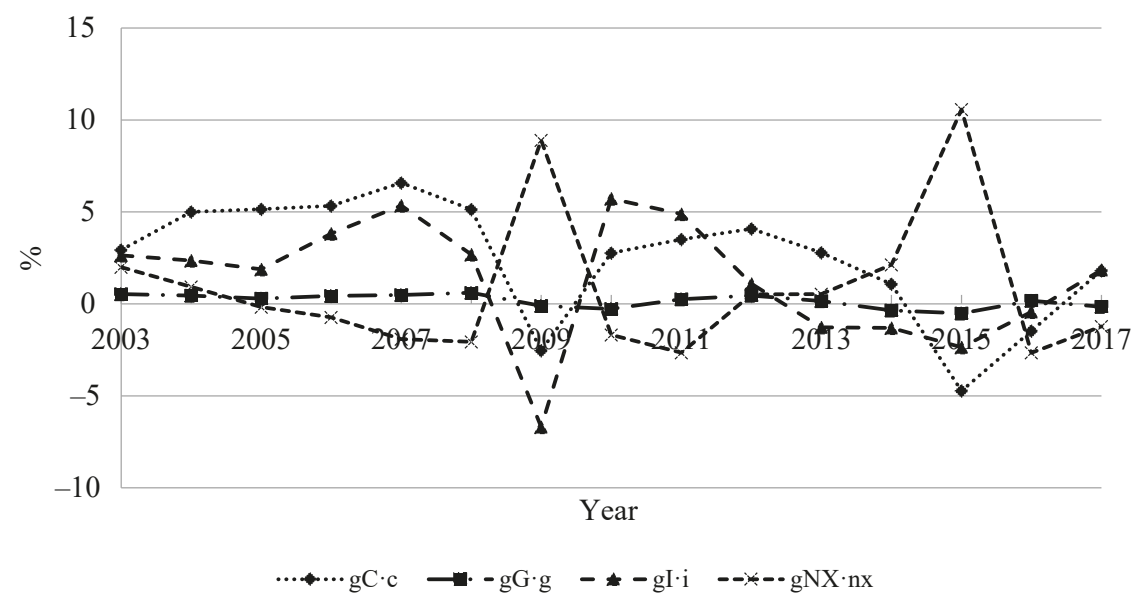

Fig. 1. Structural dynamics of Russia's GDP, 2003-2017

B a sed on: Federal State Statistic Service. URL: http://www.gks.ru/wps/wcm/connect/ rosstat_main/rosstat/ru/statistics/accounts/ (accessed: 25.02.2019).

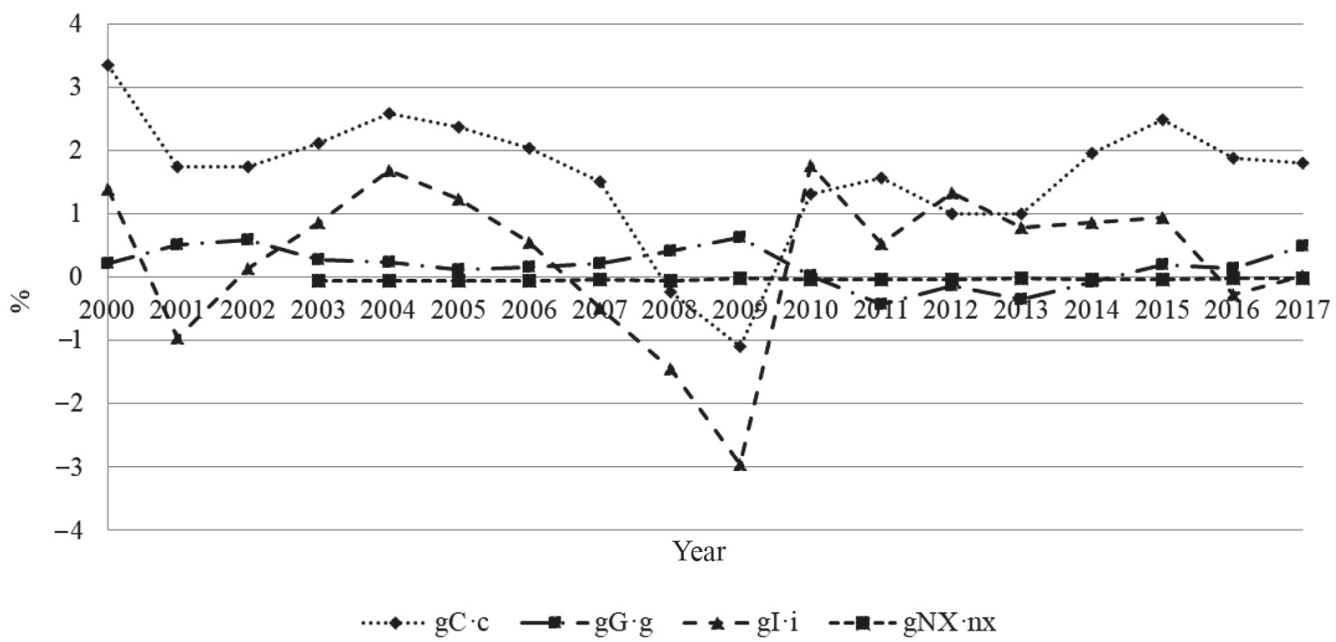

Fig. 2. Structural dynamics of the US GDP, 2000-2017

B ased on: Central Intelligence Agency. URL: https://www.cia.gov/library/publications/the-world-factbook/ (accessed: 25.02.2019). 


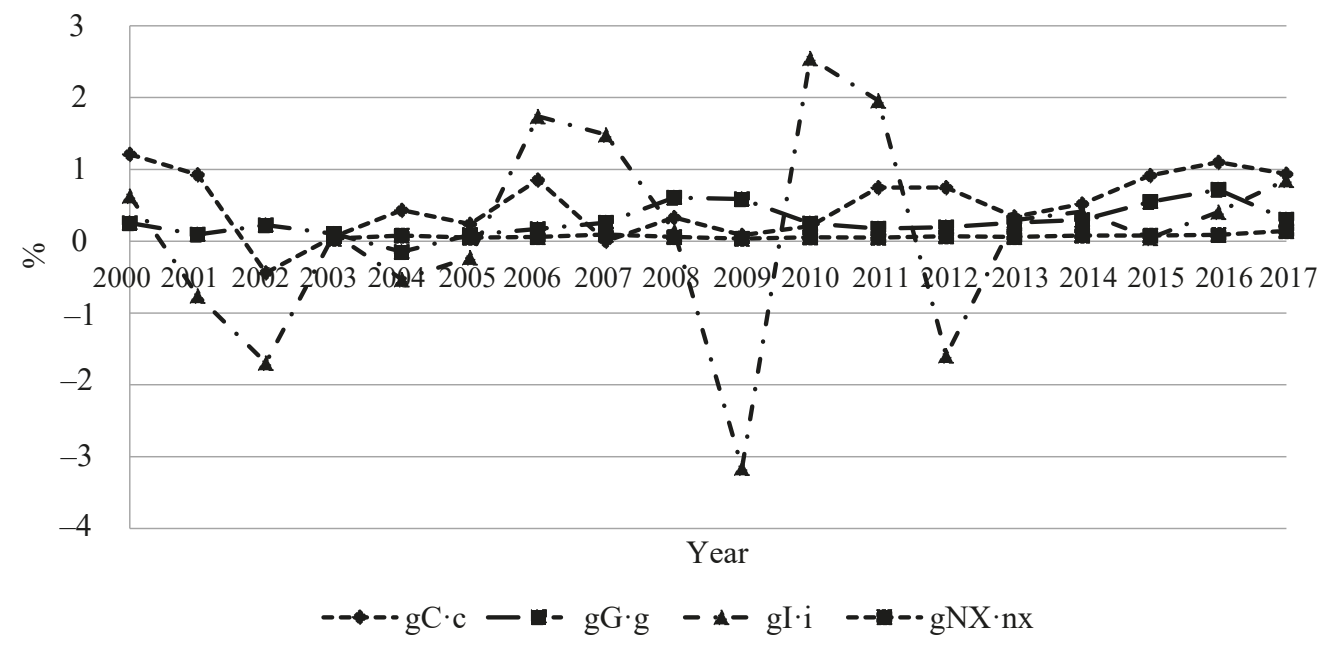

Fig. 3. Structural dynamics of Germany's GDP, 2000-2017

B a sed on: Federal Statistical Office (Destatis). URL: https://www.destatis.de/EN/Home/_node.html (accessed: 25.02.2019).

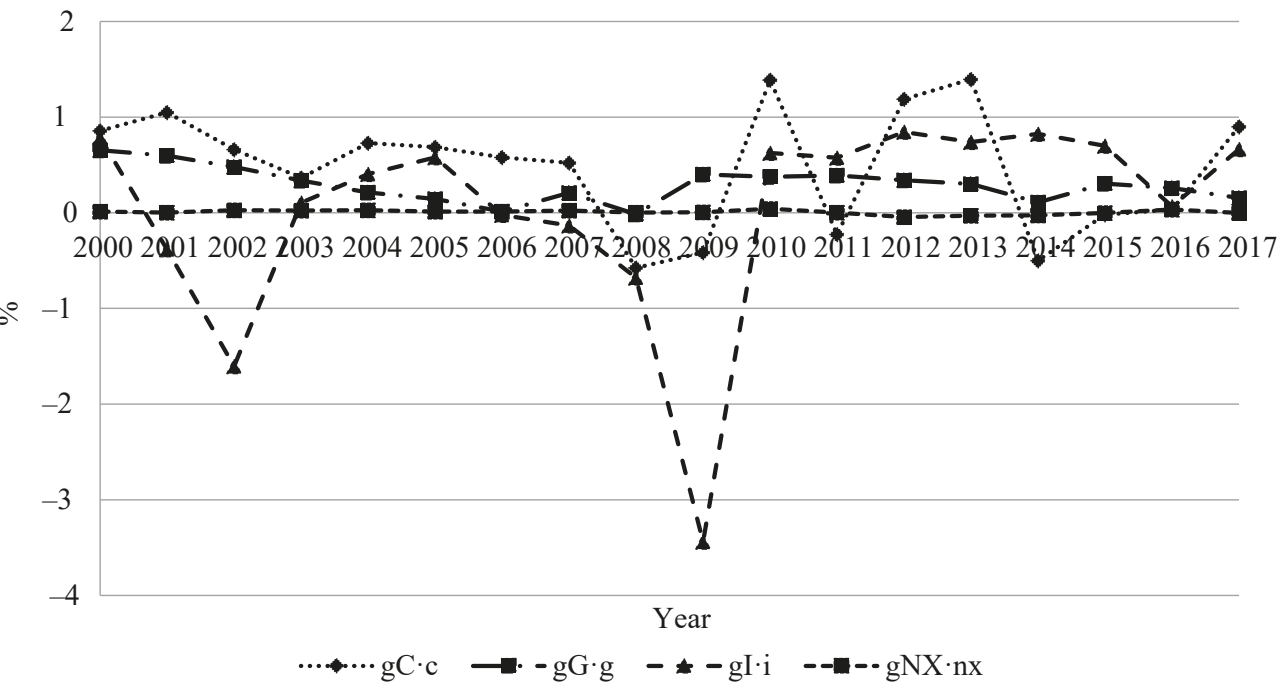

Fig. 4. Structural dynamics of Japan's GDP, 2000-2017

B a s e d o n: Statistics Japan. URL: https://www.stat.go.jp/ english/data/index.html (accessed: 25.02.2019). 


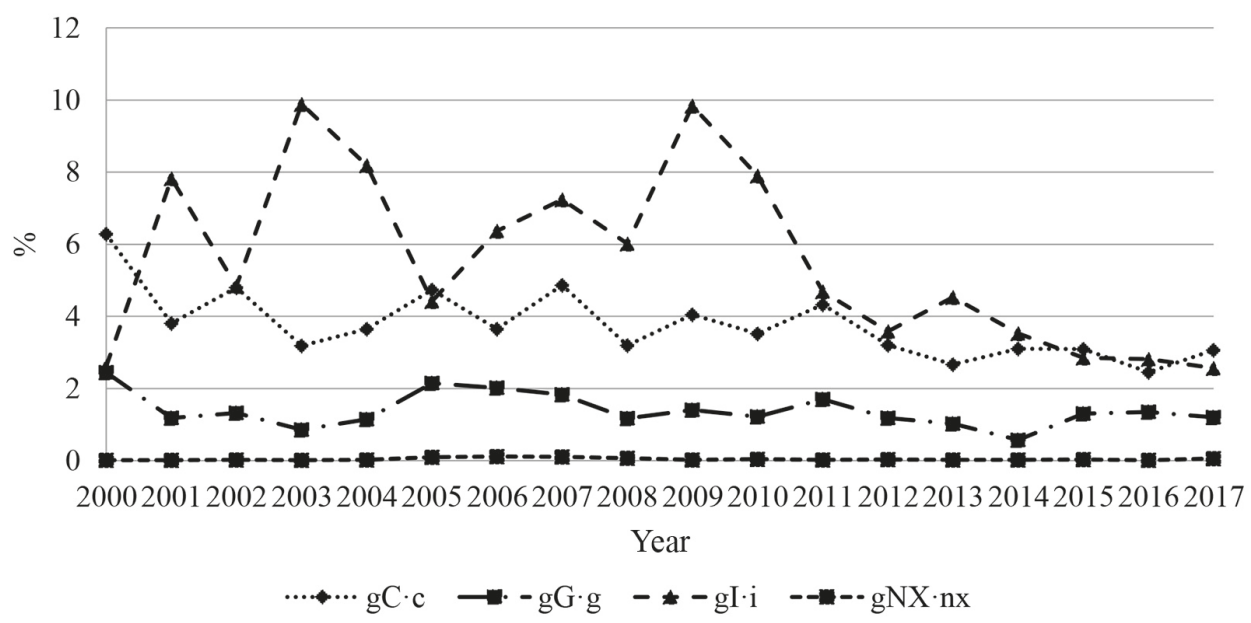

Fig. 5. Structural dynamics of China’s GDP, 2000-2017

B a se d on: National Bureau of Statistics of China. URL: https://www.stat.go.jp/english/data/index. html (accessed: 25.02.2019).

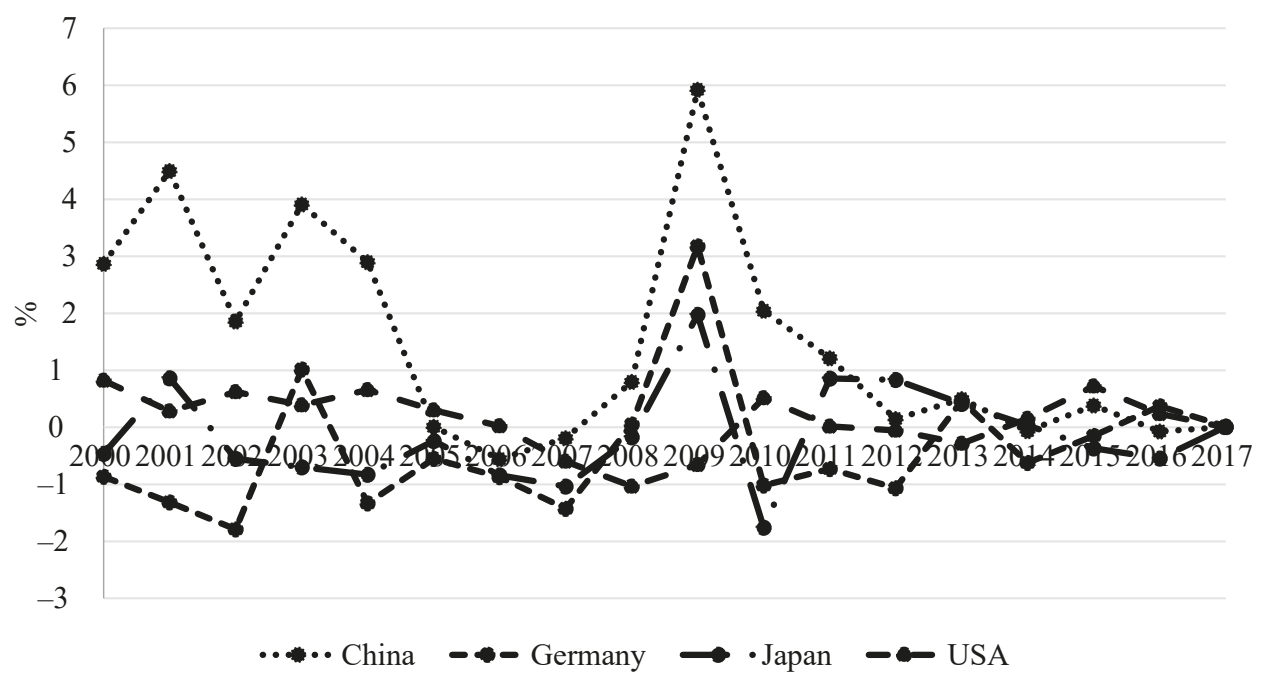

Fig. 6. Deviation of the actual from calculated rate of GDP growth, \%

B ased on: Federal State Statistic Service. URL: http://www.gks.ru/wps/wcm/connect/rosstat main/rosstat/ru/statistics/accounts/ (accessed: 28.02.2019); Russian National Bureau of Statistics of China. URL: https://www.stat.go.jp/english/data/index.html (accessed: 28.02.2019); Central Intelligence Agency. URL: https://www.cia.gov/library/publications/the-world-factbook/ (accessed: 28.02.2019); Federal Statistical Office (Destatis). URL: https://www.destatis.de/EN/Home/_node.html (accessed: 28.02.2019); Statistics Japan. URL: https://www.stat.go.jp/english/data/index.html (accessed: 28.02.2019). 


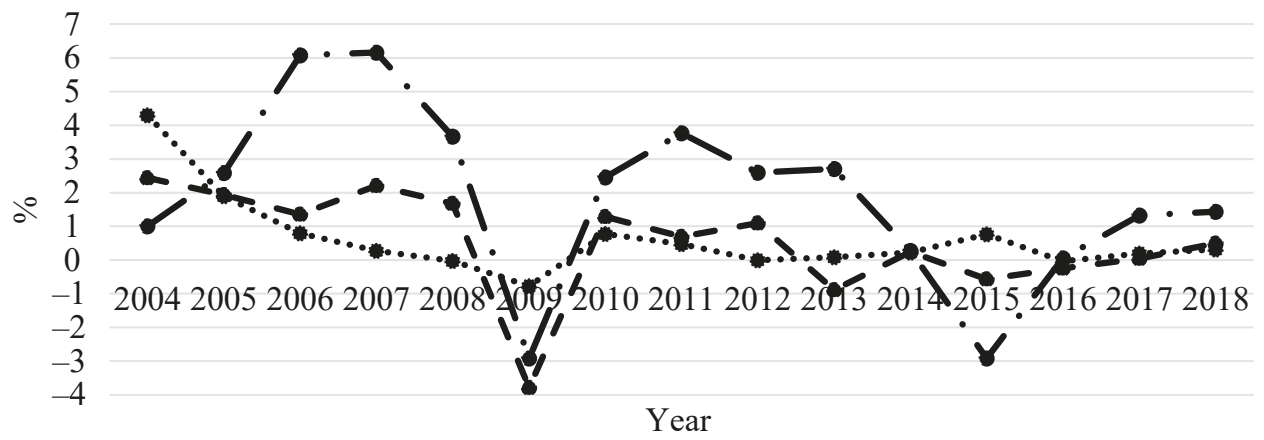

... Base material sectors, $\mathrm{gA} \cdot \mathrm{a} \quad$ - - Manufacturing activity, $\mathrm{gB} \cdot \mathrm{b}$ - Transaction sector, $\mathrm{gC} \cdot \mathrm{c}$

Fig. 7. Contribution of sectors to the GDP growth rate in Russia, 2004-2018

B ased on: Federal State Statistic Service. URL: http://www.gks.ru/wps/wcm/connect/rosstat_ main/rosstat/ru/statistics/accounts/ (accessed: 27.02.2019).

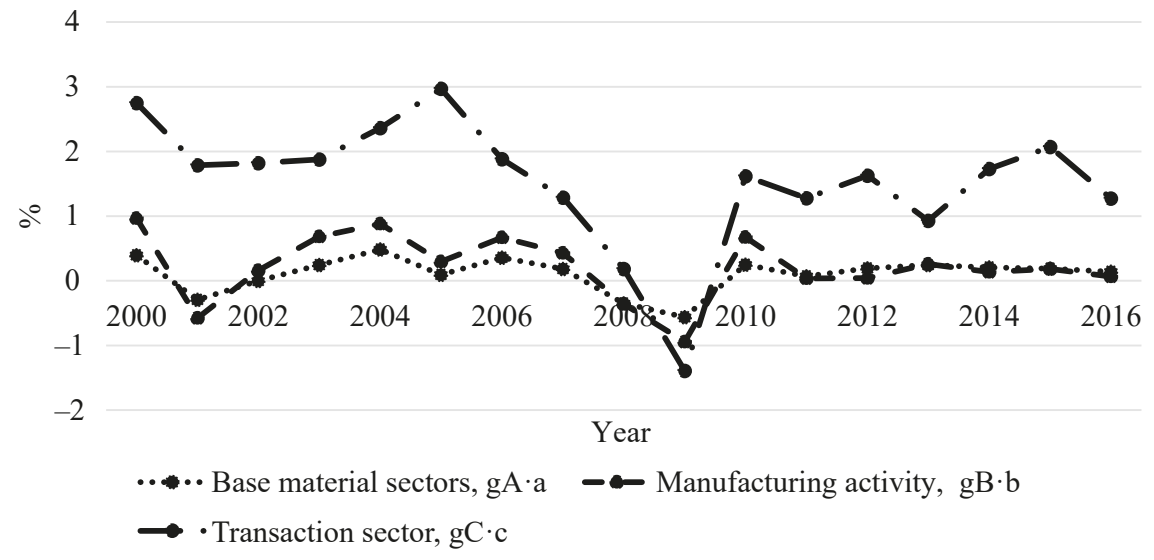

Fig. 8. Contribution of sectors to the GDP growth rate in USA, 2000-2016

B a sed on: Central Intelligence Agency. URL: https:/www.cia.gov/library/publications/ the-world-factbook/ (accessed: 27.02.2019). 


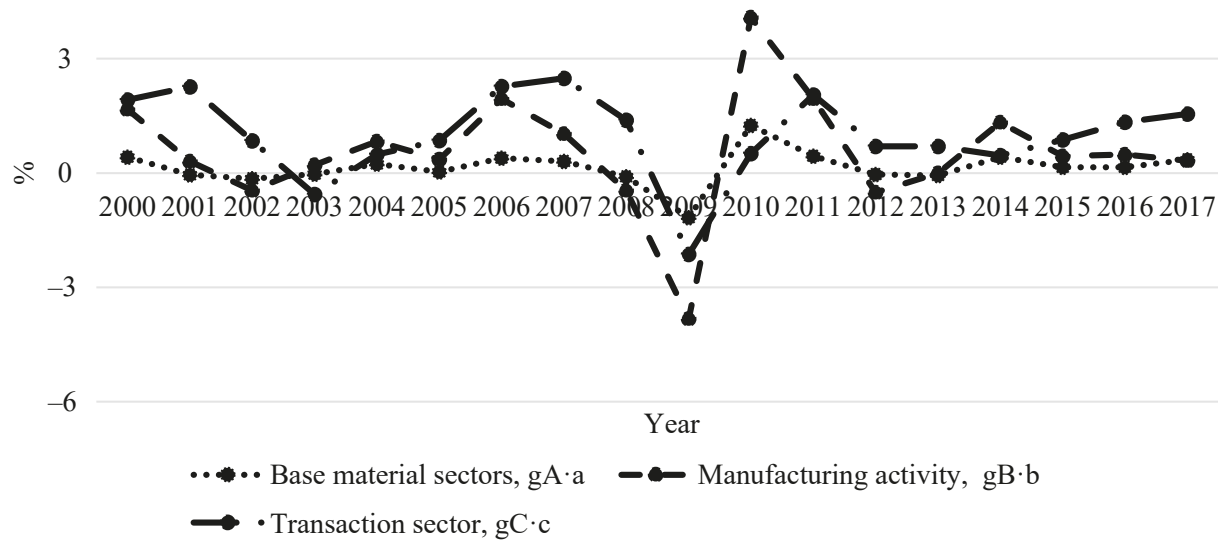

Fig. 9. Sectoral contribution to GDP dynamics of Germany, 2000-2017

B a sed o n: Federal Statistical Office (Destatis). URL: https://www.destatis.de/EN/Home/_node. html (accessed: 27.02.2019).

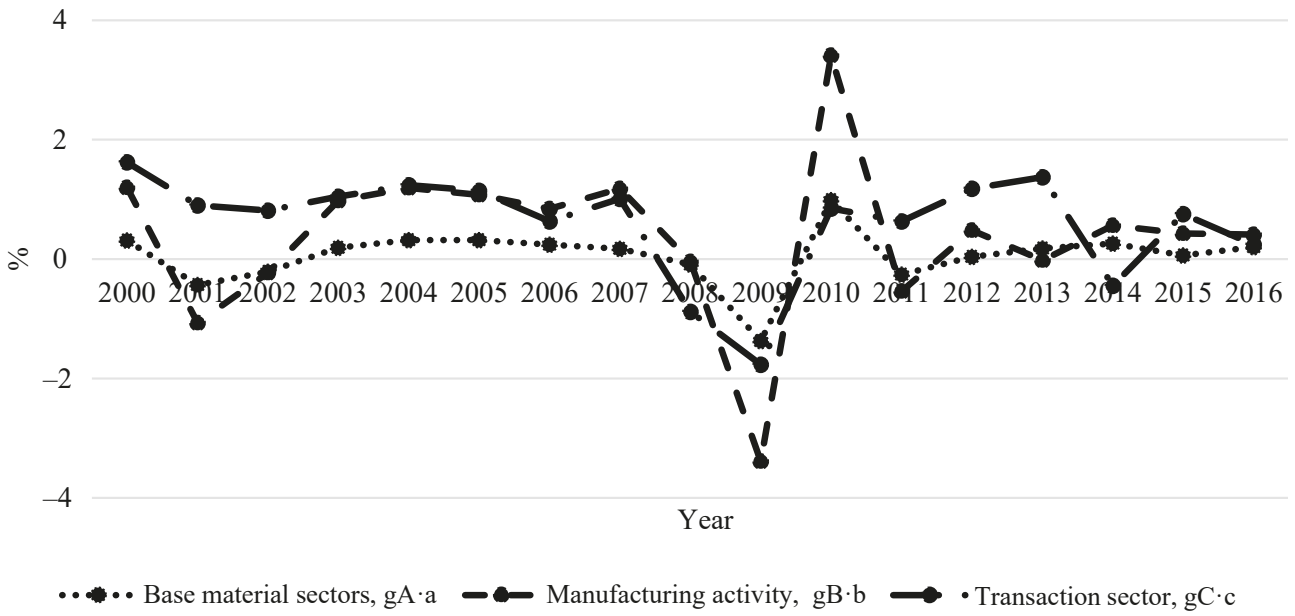

Fig. 10. Sectoral contribution to GDP dynamics of Japan, 2000-2016

B a s e d on: Statistics Japan. URL: https://www.stat.go.jp/ english/data/index.html (accessed: 27.02.2019). 


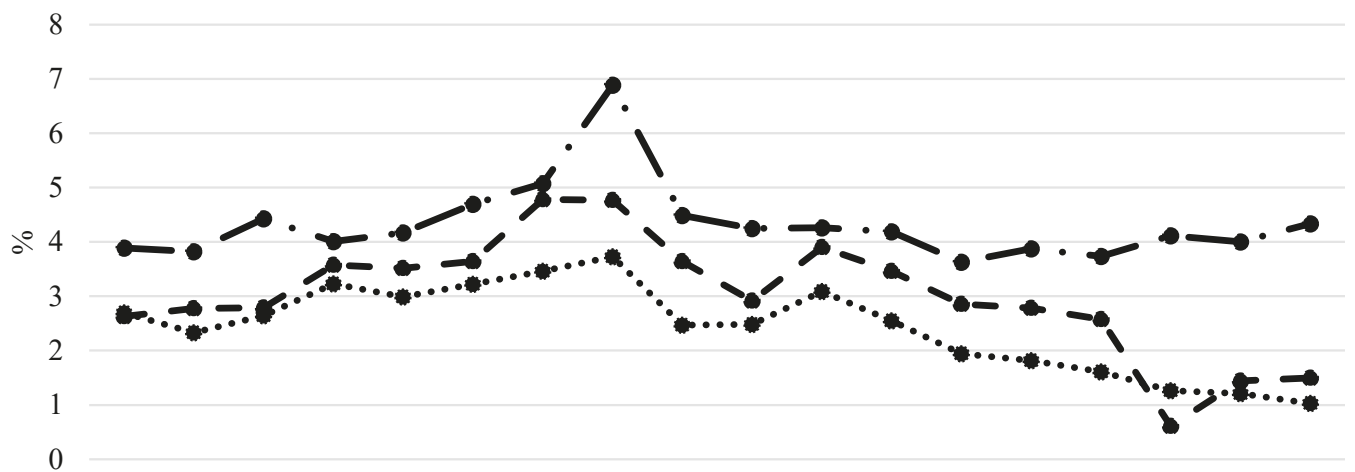

200020012002200320042005200620072008200920102011201220132014201520162017

Year

$\cdots \cdot$ Base material sectors, $\mathrm{gA} \cdot \mathrm{a} \longrightarrow \bullet$ Manufacturing activity, $\mathrm{gB} \cdot \mathrm{b} \longrightarrow$ Transaction sector, $\mathrm{gC} \cdot \mathrm{c}$

Fig. 11. Sectoral contribution to the dynamics of China's GDP, 2000-2017

B a s e d o n: National Bureau of Statistics of China. URL: https://www.stat.go.jp/english/data/index.html (accessed: 27.02.2019).

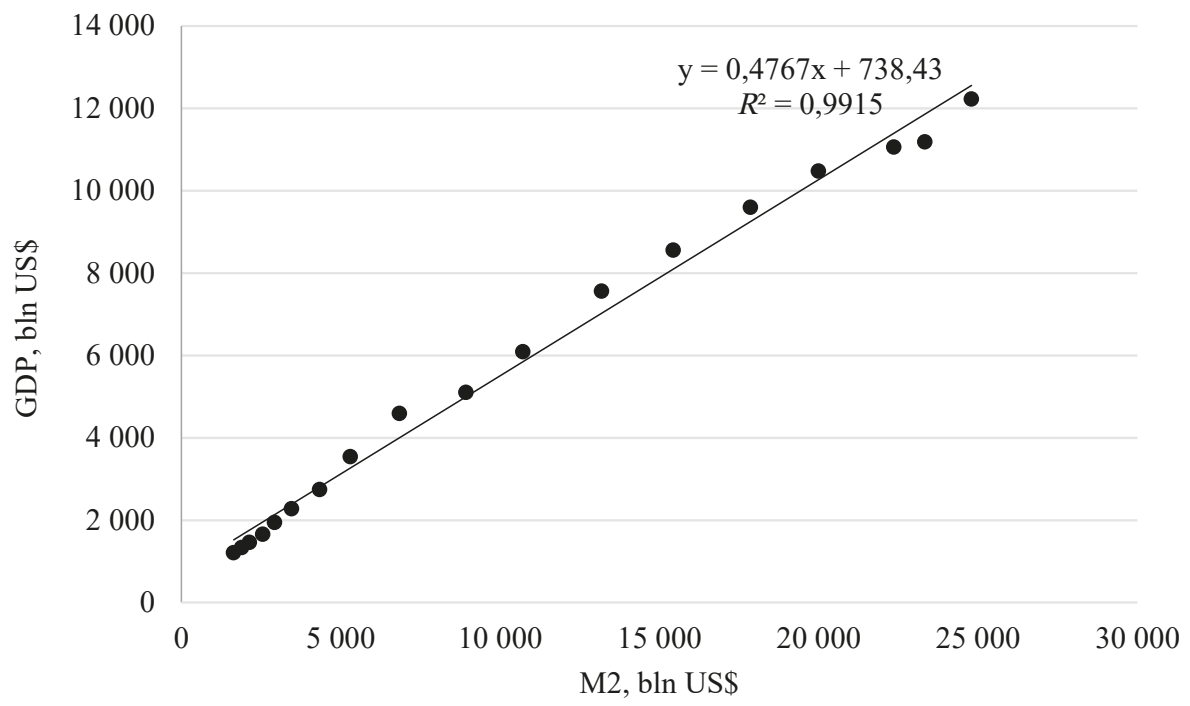

Fig.12. M2 and GDP in China, 2000-2017

Not e s: there is no residual autocorrelation in the regressions (Durbin-Watson statistic: D-Wcalcul. $\in[1.53 ; 2.47]=1.53($ left $)$ and $1.78($ right $))$, heteroskedasticity (White test: $\chi_{\text {calculated. }}^{2}(2.15$ (left) and 1.98 (right) $<\chi_{\text {critical. }}^{2}$ (3.84). F-test and Student t-test are fulfilled.

Based on: IMF World Economic Outlook Database. URL: https://www.imf.org/external/ pubs/ft/weo/2019/01/weodata/index.aspx (accessed: 20.02.2019). 


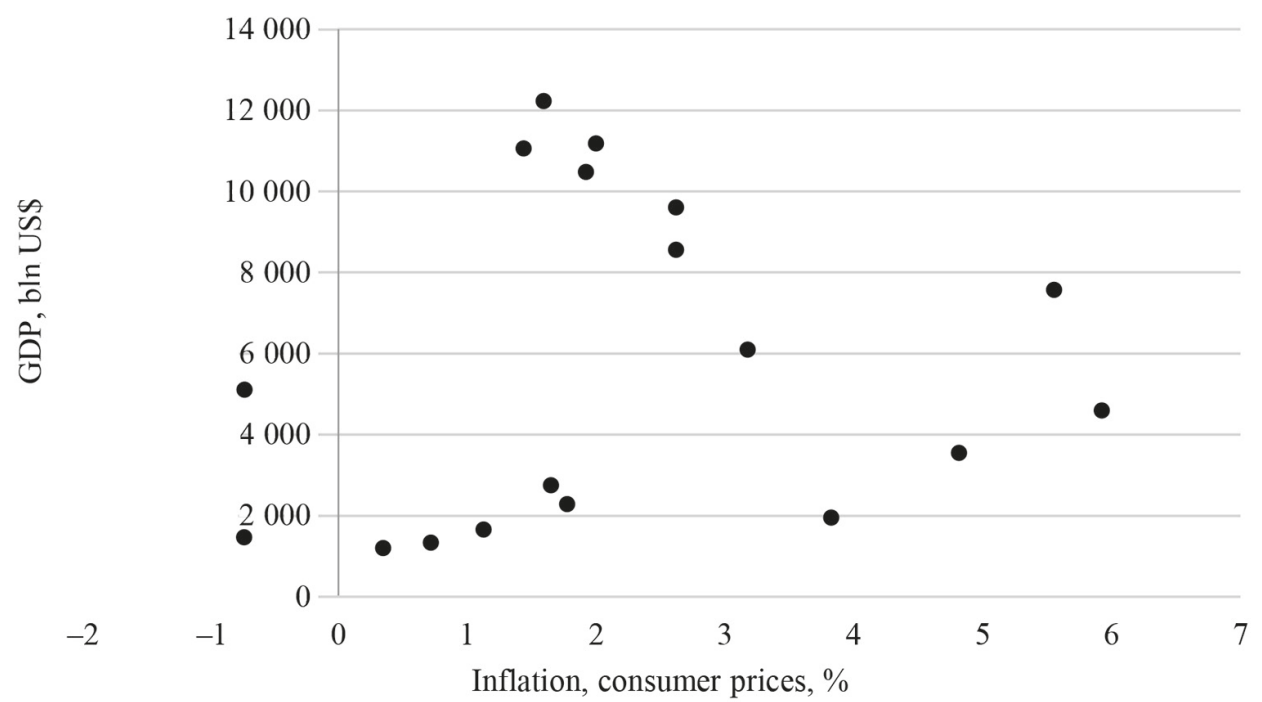

Fig. 13. Inflation and GDP in China, 2000-2017

B a sed on: IMF World Economic Outlook Database. URL: https:/www.imf.org/external/pubs/ft/ weo/2019/01/weodata/index.aspx (accessed: 20.02. 2019). 


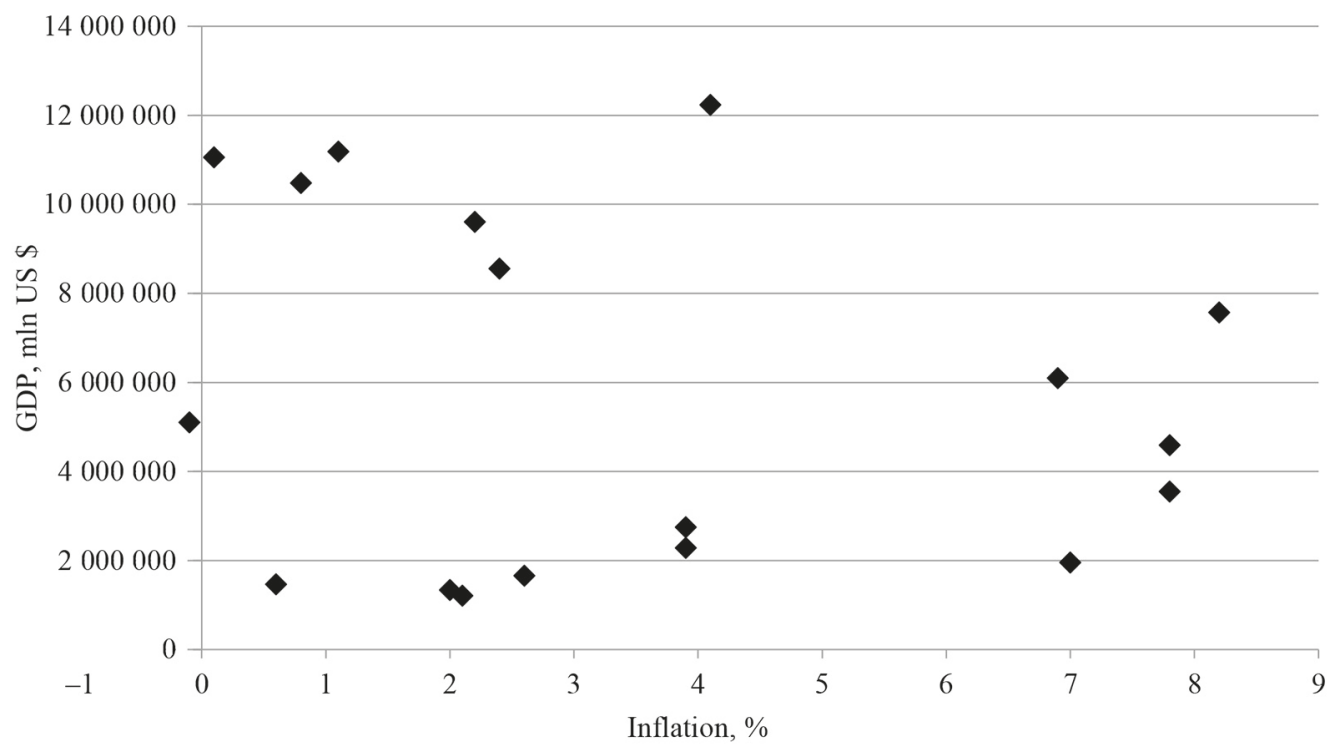

$b$

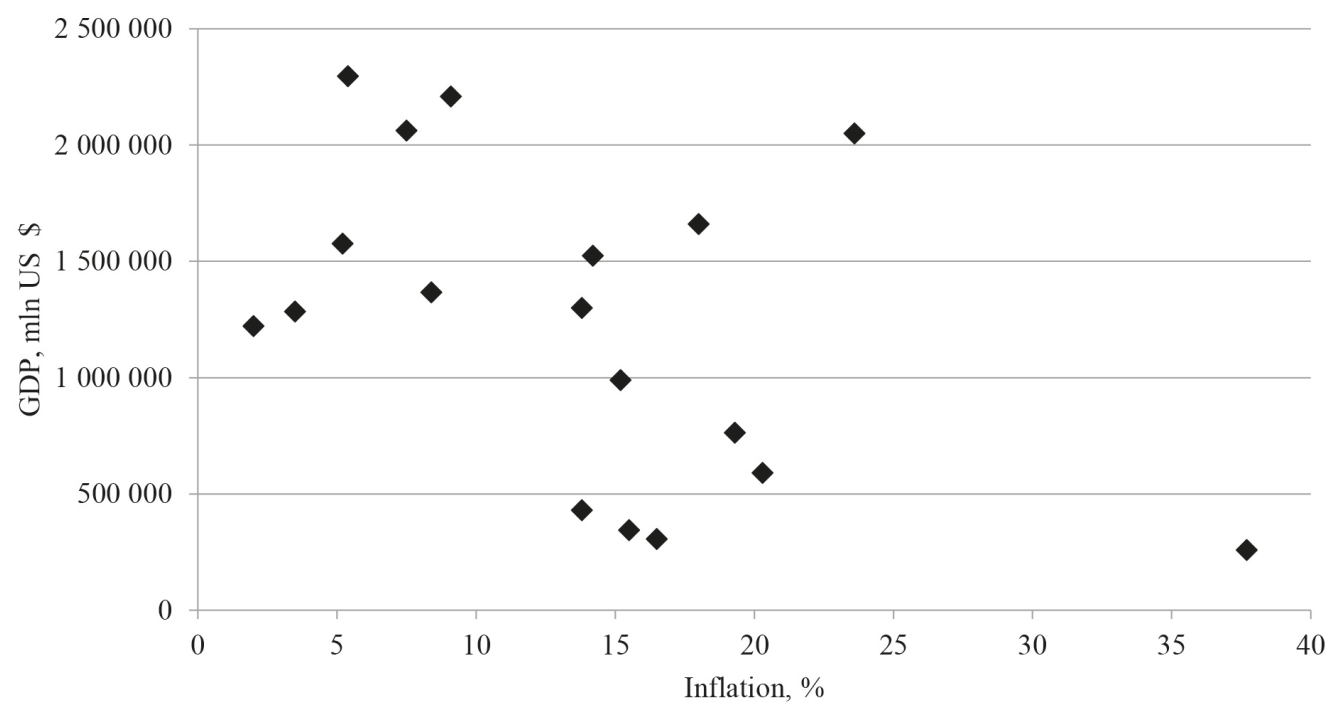

Fig. 14. Influence of inflation on GDP in China ( $a$ ) and Russia (b)

Based on: IMF World Economic Outlook Database. URL: https://www.imf.org/external/pubs/ft/ weo/2019/01/weodata/index.aspx (accessed: 20.02.2019). 


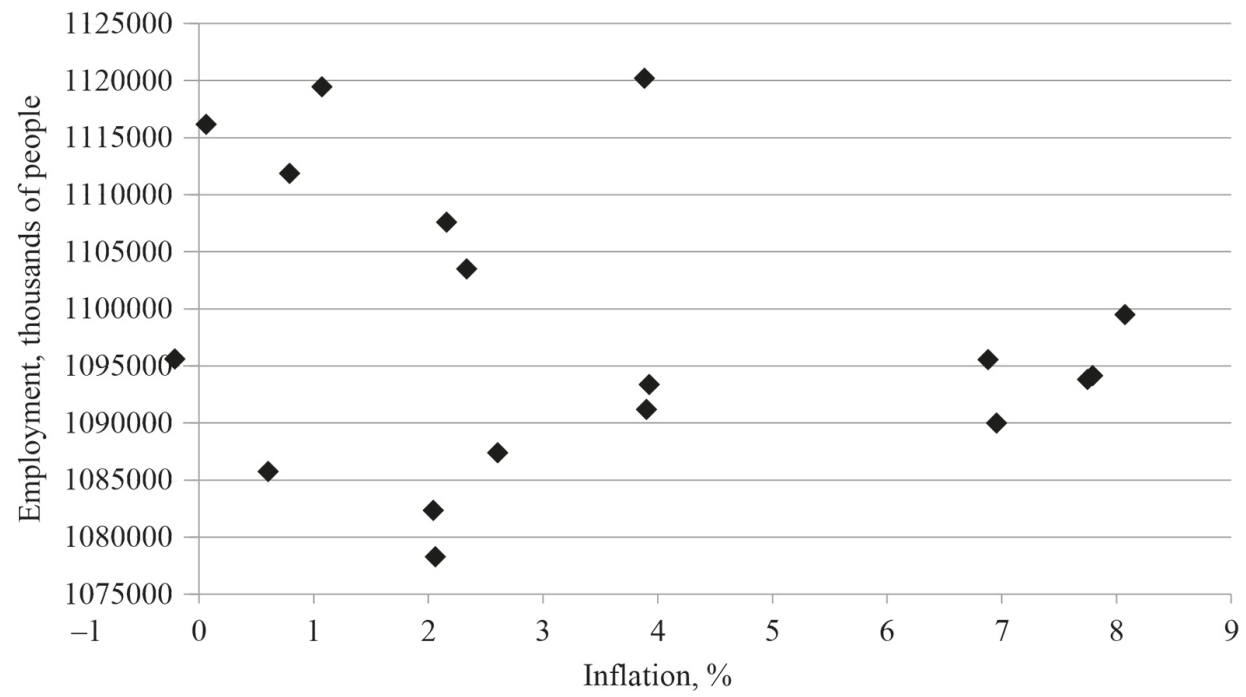

$b$

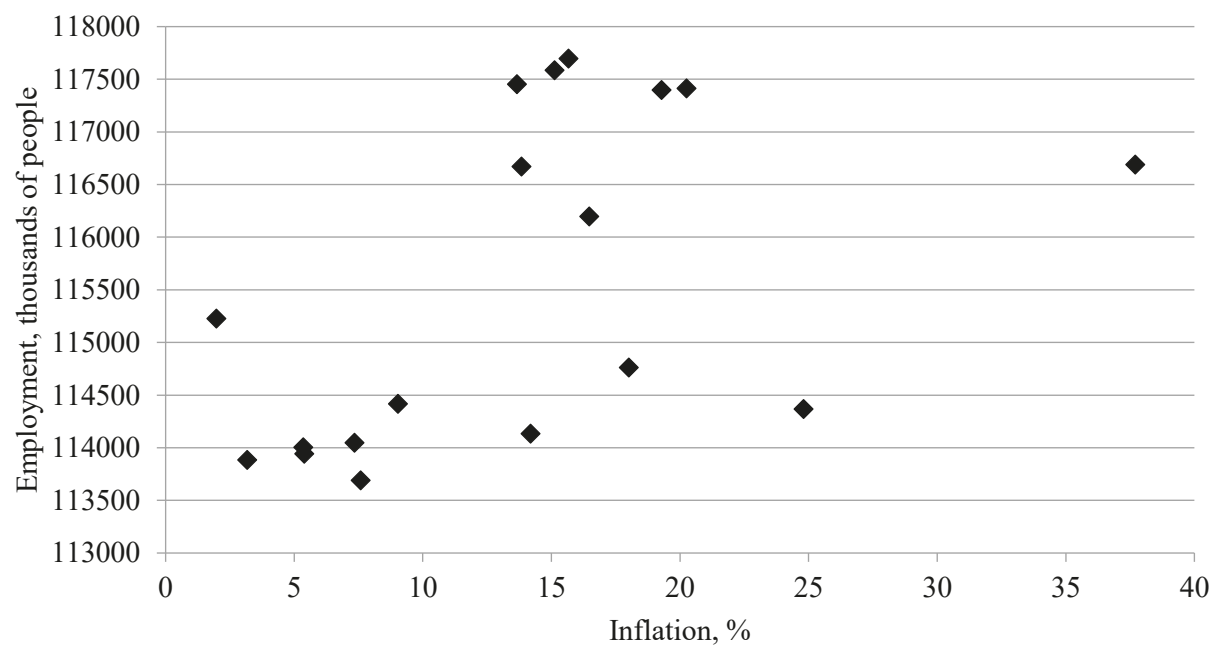

Fig. 15. Influence of inflation on employment in China (a) and Russia (b)

B a se d on: IMF World Economic Outlook Database. URL: https://www.imf.org/external/pubs/ $\mathrm{ft} /$ weo/2019/01/weodata/index.aspx (accessed: 20.02.2019). 


\title{
Структурный анализ экономического роста в Китае в контексте международных сопоставлений
}

\author{
О. С. Сухарев ${ }^{1}$, Е.Н. Ворончихина ${ }^{2}$ \\ ${ }^{1}$ Институт экономики РАН, \\ Российская Федерация, 117218, Москва, Нахимовский пр., 32 \\ 2 ФГБОУ ВО «Пермский государственный национальный исследовательский университет», \\ Российская Федерация, 614990, Пермь, ул. Букирева, 15
}

Для цитирования: Sukharev O.S., Voronchikhina E.N. (2019) Structural Analysis of Economic Growth in China: International Comparison Context. Вестник Санкт-Петербургского университета. Экономика. Т. 35. Вып. 4. С. 543-568. https://doi.org/10.21638/spbu05.2019.403

Китайская экономика в течение длительного времени демонстрирует относительно среднемировых высокие темпы роста, несмотря на их постепенное замедление на протяжении последних лет. В этой связи важно определить особенности модели и политики экономического роста в сравнительном аспекте с другими странами. Целью исследования является проведение структурного анализа экономического роста китайской экономики в сравнении с США, Германией, Японией и Россией, а также установление особенностей ее структурной динамики и проводимой макроэкономической политики. Предмет исследования - сложившиеся модели экономического роста данных стран, подходы к макроэкономической политике роста в Китае и России, определение вклада компонент ВВП и секторов экономики в темп экономического роста. Полагаем, что модель роста экономики определяется доминированием компоненты и сектора в валовом внутреннем продукте, т. е. структурными характеристиками экономической динамики, а также поддерживающими такую динамику мерами макроэкономической политики. Результатом применения метода структурного анализа стала идентификация моделей экономического роста. Определены три базовые модели роста: на основе доминирования валового потребления (США, Россия), на основе инвестиций (Китай) и смешанная модель роста (Германия и Япония). На базе структурного анализа показано, что китайская экономика близка к модели роста Шумпетера, когда подавление инфляции не является безусловным требованием для стимулирования роста, а зависимость Филлипса не действует. Российская экономика показывает рост, близкий к модели Фишера, особенно в части требований к макроэкономической политике, когда условием роста становится подавление инфляции. Следовательно, для обеспечения инвестиционной модели роста необходимо, помимо стимулирования инвестиций, изменить характеристики структурной динамики, в том числе за счет смены инструментов макроэкономической политики, воздействующих на макропараметры, - инфляцию, процентную ставку, денежную массу, занятость.

Ключевые слова: эмпирический анализ роста, структура валового внутреннего продукта по расходам, секторальная структура экономики, сравнительный анализ, модель экономического роста.

Статья поступила в редакцию 22.03.2019

Статья рекомендована в печать 11.09.2019

Контактная информация:

Сухарев Олег Сергеевич — д-р экон. наук, проф.; o_sukharev@list.ru

Ворончихина Екатерина Николаевна - канд. экон. наук; envoronchikhina@gmail.com 